\section{Saudade gostosa Sobre la comida, el hombre, la cultura y su representación}

\section{Carmen Rosa Vargas}

$W_{\text {osotros, al igual que todos los }}^{\text {otros mamíferos terrestres, lo pri- }}$ mero que sabemos hacer, apenas nacemos, es comer. Tomamos la leche del pecho de nuestra madre y así descubrimos lo que significa "el placer". El placer de comer. Después de algún tiempo descubrimos también que somos homo sapiens y ahí la cosa se complica. Dice Nietzsche que la palabra griega que designa al "sabio" viene etimológicamente de "sapio", que quiere decir "yo saboreo", de sapiens: "el degustador". Interpretándolo de la mejor manera, el hombre, antes que racional, es degustador. Él degusta y escoge.

Cuando tenía unos tres o cuatro meses viviendo en Río de Janeiro, me preguntaron una vez:

— ¿Qué cosa extrañas más de tu tierra?

Fue una pregunta difícil de responder, porque sentía añoranzas de todo. Pero haciendo el ejercicio de pensar dije que lo que más extrañaba era la comida de mi mamá.

La comida y su relación con el hombre viene desde que nuestro instinto animal nos ordenaba saciar el apetito y teníamos que cazar, pescar o trepar los árboles para conseguir alimento. Pero esta relación se vuelve un "caso de amor" cuando el hombre descubre que podía preparar sus alimentos, cocerlos al fuego, cambiando así 
su sabor, olor y contextura; haciéndolos mucho más sabrosos. No es a propósito que es un "degustador".

$*$

En Sao Paulo fui al cine y me encontré con el anuncio de un conversatorio muy interesante titulado: "Salsa, cebollita y celuloide”. Decía así:

Dedicada a gourmets y cinéfilos, esta muestra presenta imágenes que sugieren los más variados aromas y paladares en una selección de filmes que mezcla los placeres del mirar con los de la buena mesa. Receta y sazón, sabor e imagen. Los más exquisitos aderezos: seducción y (alguna) crueldad. Todo para degustarse con la firma de los grandes chefs del cine...

Cocinar es mezclar, experimentar, intentar. Los nutricionistas pueden decir que eso obedece a las necesidades vitales de complementar la dieta, buscar las proteínas, las vitaminas, los carbohidratos y azúcares, la química del sustento y de la sobrevivencia. Eso, sin duda, es válido, pero podríamos decir también que en el apetito de universalidad de la comida existe siempre un impulso característico de la cultura. Los alimentos que preparamos, además del clima, de la geografía y la tradición que los determinan, son condicionados, lógicamente, por el hambre que tenemos, mas también y principalmente por el placer que su variedad de sabores y colores nos da.
En una fiesta en casa de uno de esos amigos raros que tenemos cuando vivimos en otro país, me ofrecieron un bocadito muy sabroso. No pude contener mi curiosidad y entré a la cocina. Ahí estaba la dueña de la casa y comenzamos a conversar. Ella era de Tailandia. Después de un buen tiempo de terturlia finalmente me dice:

—En mi país tenemos la costumbre de coleccionar toda la vida nuestras recetas favoritas, ellas serán distribuidas en el entierro de cada uno...

El tránsito de la alimentación - como condición natural para compensar el gasto de energía corporal y sobrevivir- a la gastronomía reside precisamente en esa dosis inconmensurable de curiosidad, gusto e imaginación que hace que el hombre le otorgue a la comida una dimensión lúdica, de fábula, de sensualidad. Los cristianos pueden sentir conmoción o ceremonia de pecador ante la comida. La continencia ha sido siempre un alto valor cristiano, señal de victoria del espíritu sobre las solicitudes del cuerpo: "prisión del alma". En la cultura cristiana existe la "satanización" de los placeres corporales (y el buen comer es uno de ellos), pero vive al mismo tiempo la divinización cortesana de la comida. Esa dialéctica de tensión frente a la gula es casi la misma que amenaza al cristiano entre la fe y la herejía, entre 
la solidaridad y el individualismo, entre la caridad y la sinvergüenzura.

\section{$*$}

Por motivos de trabajo fui con algunas personas a un restaurante muy elegante, cuyo chef era suizo como el queso y cocinaba maravillosamente.

—Mis felicitaciones al chef — dije—.

No pasaron ni cinco minutos y el chef Piaget se apareció frente a mí para agradecer la deferencia. Me preguntó de dónde venía.

—Soy peruana —le respondi-.

-Para mí, las tres mejores comidas del mundo son: la francesa, la china y la peruana —dijo él para mi sorpresa-.

—Usted dice eso por cortesía —argumenté-

¥o digo eso porque así pienso -merespondió-.

—iPor qué piensa que mi comida es tan buena? -insistí-

- Por la convergencia de tradiciones, por las materias primas tan extraordinarias, los productos del mar, las hierbas peruanas, el limón, la papa, el "choclo" y porque ustedes saben comer y exigen -fue su respuesta.

Todos los pueblos creen que su comida es la mejor de todas. Ese es el precio obligado del antropocentrismo casi genético de los pueblos y culturas. Eso explicaría que, en la medida en que la necesidad de afirmarse como de "algún lugar" amenaza y muerde en tiempos de globalización y pérdida de valores propios, el interés por la gastronomía sobrepasa los códigos del "gozo gustoso" para convertirse en brújula de desorientados, en perro guía de los ciegos, en enseñanza de patriotas. Pero la cultura - y la gastronomía hace parte de ella- es esencialmente heterogénea, múltiple, ajena al forzado cinturón de castidad que supone todo nacionalismo. No existen culturas autónomas; unas a otras se prestan hallazgos y conquistas, aunque sean estas por guerras, invasiones o depredaciones. La historia de cada pueblo, de cada cultura o de cada arte podría dividirse según la calidad de las invasiones sufridas.

México, 1890. Tita es la menor de tres hijas de una viuda aristócrata, dueña de tierras y haciendas (el marido murió cuando se dio cuenta de que una de las hijas no era de él). Por tradición familiar, Tita nunca se podrá casar, ella es la encargada de cuidar a su madre, hasta que alguna de las dos muera... Cuando Tita sintió sobre sus hombros la ardiente mirada de Pedro, comprendió perfectamente lo que debe sentir la masa de un pastel cuando entra en contacto con el aceite hirviendo... Era tan real la sensación de calor que la invadía, que ante el temor de que, como a un pastel, le comen- 
zaran a salir burbujas por todo el cuerpo, el vientre, el corazón, los senos... bajó su mirada e intentó huir.

(Como agua para chocolate

Director: Alfonso Arau.- México, filme basado en la novela homónima de Laura Esquivel).

La gastronomía puede entenderse en el mundo lírico, artístico, poético... no racional, dentro del hecho de la comida. Es como mirar hacia el interior; hablar sobre su comida es un hecho que cada pueblo hace suyo y del cual se siente muy orgulloso. Es difícil entender que exista algún país o pueblo que no ame su cocina, pero es normal en cambio escuchar a alguien que viene de muy lejos decir que su comida es (después de algunas otras para no pecar de poca humildad) además de original, la más atrevida: la mejor del mundo. Bien o mal entendido, él "comunica" su comida, la divulga, cuenta sus maravillas y los secretos que en ella existen. Son sus fuentes, sus raíces dadas a conocer. Paradójicamente, la comida siempre resulta del encuentro de dos fuerzas no siempre "al punto" que nosotros desearíamos, pero hay veces que dan buenos resultados. Los ingredientes de nuestra comida son una mixtura de culturas. En esa mesa no solo se sientan los ingenuos señores incas y los bien amados españoles, también se sientan gitanos de la Almería con los nazcas y los mayas, los moro-moros de Mauritania saludan a los griegos por su aceite y estos a su vez los felicitan por sus aceitunas. Gringos de Flandes comentan con los visigodos lo mucho que comen los mandarines sin trenzas, en cuanto los principitos de Paracas son conquistados por el olor de las sabrosuras africanas entre el tabaco y el ron...

\footnotetext{
Ella continúa cocinando, entretanto él va probando los platos que ya están listos... Ella: No puedo cocinar en casa.

Él: ¿En aquella cocina grande?

Ella: Sí, es la cocina de papá. Si cocinara ahí, yo estaría humillándolo.

Ella coloca ajo en la sartén con aceite caliente. Una olla está hirviendo. Todos los platos están listos. Ella sirve.
}

Ella: Carpa con salsa de ajo, el primer plato que tío Wem me enseñó.

Ella trae un plato más y finalmente se sienta a la mesa.

Ella: Y este pato sauté con arveja. Dos platos, dos sabores: frío y caliente, balanceado. Es filosofía antigua: balancear con energía, sabor y naturaleza.

(Escena del filme Comer, beber, vivir. Director: Ang Lee, China).

La relación entre el pasado, el presente y el futuro es distinta en cada cultura. Para las civilizaciones de Oriente y del Mediterráneo o para las de la América precolombina, el pasado siempre es un tiempo que reaparece y que nos espera al final de cada periodo. El pasado viene a ser a su vez el futuro y el inicio, el tiempo no 
se gasta ni se termina. Siempre está ahí, con la "mesa servida". El pasado siempre vuelve, se presenta en el rito, en la fiesta, en la comida. Para los cristianos, occidentales en cambio, el futuro no se parece al pasado ni al presente: es lo inesperado. Pero viene pronto, el tiempo termina y cuando termine es mejor tener al lado el pan y el vino, en cuerpo y en alma.

Dicen los eruditos en gastronomía que el mestizaje, por lo menos en América Latina, se inició en la cama y en la cocina. Que la forma como el conquistador se fue mixturando con el poblador americano de ese momento es a través de los usos del amor y del comer. El mestizaje es la capacidad de adaptación y traducción, la síntesis de dos fuerzas. La gastronomía de cada país es el reflejo de la influencia del mundo en los testimonios de las cocinas originales, regionales, cotidianas y rituales.

La comida es el sabor de la cultura, pues toda cultura se estructura en función de la satisfacción de las necesidades básicas del hombre como el comer, el beber, el sexo y el sueño. La satisfacción de estas va a definir un tipo de actitud, un tipo de actividad, una forma de resolver que va a determinar el carácter de esa cultura en función de lo que hacen las sociedades para resolver estas necesidades primarias y después, naturalmente, creando necesidades ya sociales para ir resolviéndolas cada vez más, hasta llegar a una su- tileza, a un desenvolvimiento de la civilización que, sin duda, nos coloca a una gran distancia de las culturas primitivas y que no es otra cosa que esta cada vez más eficaz satisfacción de las necesidades. Naturalmente, la comida es una necesidad central, una de las más significativas alrededor de la cual se ha estructurado gran parte de la historia: el descubrimiento de América fue una respuesta al deseo de comer bien. Obviamente no todos los individuos tienen la disposición y el paladar para saborear bien; es como el sentido para la música o la literatura. No todos estamos bien dotados.

\[ \]
Les menu de les chefs cuisinier
SAMEDI
Escargot Français
Corvina Flaubert
(hébergement à salsa de beurre camaro-
nes et avocatier tibia)
Sole à Salsa de Jaiba
Clafoutis aux Kiwi
(Menú del día sábado. El cocinero, el
$\quad$ ladrón, su mujer y el amante

Director: Peter Greenaway, Francia).

La gastronomía es la expresión cualitativa que caracteriza la cultura alimenticia de un país o de una región. El gastrónomo, por lo tanto, representa la suma de conocimientos que se adquiere por los sentidos del olfato y el pala- 
dar; esto permite distinguir cualitativamente los sabores y aromas de los alimentos y líquidos. Hoy ocurre un fenómeno que se va multiplicando de manera inquietante; cada vez hay más gente que mira sin ver nada, que escucha sin entender nada, que habla sin decir nada. Sufren de un nuevo virus de nuestra sociedad: el virus de lo light. Las recetas tradicionales se van perdiendo para convertirse en esa comida simple y llena de nada, pero que es rápida y eficaz. ¿Será que poco a poco estamos entrando a una cultura light que va perdiendo su sabor?, ¿será que resolveremos eso con una rectificación o será que con el tiempo parecerá que la cultura light y su comida van a ser delicias comparadas con lo que se comerá después?... Mientras tanto, felizmente, existen los gastrónomos por vocación más que por diploma, la vida los convida a una búsqueda por la calidad y la perfección. Un gastrónomo no es necesariamente un cocinero, así como un crítico de cine no es un cineasta. Existen un sinnúmero de asociaciones gastronómicas cuyos miembros son COnocedores y aficionados a la gastronomía. Estas constituyen una defensa frente a las falsificaciones y al descalabro de la autenticidad de las recetas originales. Su existencia y su labor son fundamentales para la supervivencia de la gastronomía propia de algún país. Curnosky, el príncipe electo de los gastrónomos, decía que existen dos tipos de cocina: la buena y la mala.
La cultura de un pueblo es el reflejo de su gastronomía y a los pueblos refinados compete tener la mejor mesa. Conservar las tradiciones culinarias debiera ser un deber, pues ellas forman parte de la identidad de un país; abandonarlas es negar y destruir el pasado. Nuestra cultura va a girar en torno a las cosas que hemos vivido desde nuestro nacimiento y se irá perfeccionando con la tradición. Cada uno de nosotros come su propia cultura, sus propias tradiciones y su propia emoción.

Finalmente, les digo a mis invitados: la mesa está servida. Es posible que este plato tenga "cine" de más y poco de otras artes. No es una disculpa, es solo un límite. Cada chef tiene su propia sazón que viene de su casa $\mathrm{e}$, inconsciente o conscientemente, él usa las cosas que ya conoce. El cine, así como la comida, es reflejo de la cultura, además que comunica y aprehende, degusta y escoge. La representación de la comida a través del cine no solo acaba con las añoranzas, saca el polvo de los recuerdos y presenta la historia de un pueblo a otros habitantes del mundo, junto con sus costumbres, sus valores, sus pecados y sus dones. Pero la comida también es representada en la música, en la pintura, en la fotografía, en la televisión, hasta en la internet... Está ahí, para todos los gustos y colores, para cualquier paladar, hasta para el más exquisito. Es solo cuestión de querer probar... 